\title{
The "Persuadable Middle" on Same-Sex Marriage: Formative Research to Build Support among Heterosexual College Students
}

\author{
Michael R. Woodford • Jill Chonody • \\ Kristin Scherrer • Perry Silverschanz • Alex Kulick
}

Published online: 20 November 2011

(C) Springer Science+Business Media, LLC 2011

\begin{abstract}
Same-sex marriage is a controversial policy issue that affects the welfare of gay and lesbian couples throughout the USA. Considerable research examines opinions about same-sex marriage; however, studies have not investigated the covariates of the "persuadable middle"those individuals who are neutral or unsure about their views. This group of people is often the target of same-sex marriage campaigns, yet they have received no empirical attention.
\end{abstract}

\author{
M. R. Woodford $(\square)$ \\ School of Social Work, University of Michigan, \\ 1080 S. University Avenue, \\ Ann Arbor, MI 48109-1106, USA \\ e-mail:michwood@umich.edu \\ J. Chonody \\ School of Psychology, Social Work and Social Policy, \\ University of South Australia, \\ St. Bernards Rd., \\ Magill, South Australia, Australia 5072 \\ e-mail: Jill.Chonody@unisa.edu.au

\section{K. Scherrer} \\ School of Social Work, Rutgers, \\ The State University of New Jersey, \\ 536 George St., \\ New Brunswick, NJ 08901, USA \\ e-mail: kscherrer@ssw.rutgers.edu \\ P. Silverschanz \\ School of Social Work \& Department of Psychology, \\ University of Michigan, \\ 1080 S. University Avenue, \\ Ann Arbor, MI 48109-1106, USA \\ e-mail: pgrin@umich.edu

\section{A. Kulick} \\ Women's Studies, University of Michigan, \\ 1080 S. University Avenue, \\ Ann Arbor, MI 48109-1106, USA \\ e-mail: alkulick@umich.edu
}

Using a sample of heterosexual college students, we conduct multinomial logistic regression to identify the factors associated with being neutral about same-sex marriage. Findings suggest that in comparison with those who endorse or oppose same-sex marriage, political ideology and views about the acceptability of same-sex relationships are influential in determining the "persuadable middle." Within each category other factors are identified. We discuss the implications for policy advocacy efforts to advance marriage equality.

Keywords Same-sex marriage · Gay · Lesbian · Legal rights $\cdot$ Heterosexism $\cdot$ College students

Without question, same-sex marriage is an issue where the vast majority of voters on each side already made up their minds - and no amount of campaigning would change their opinions. Elections come down to just the sliver of undecided voters - maybe 5\%-who don't know or think much about the issue.

Paul Hogarth, June 16, 2010

Beyond Chron, San Francisco's Alternative

The legal status of same-sex relationships is a contentious policy issue in the USA. Policy debates about same-sex marriage span both federal and state levels of government and have considerable implications for gay and lesbian couples (Woodford 2010). Pollsters and academic researchers have investigated opinions about same-sex marriage since the 1990s (Avery et al. 2007; Brewer and Wilcox 2005). Studies have identified covariates of opinions toward same-sex marriage; however, research has not investigated the covariates of reporting "neutral" or "undecided." Yet, these individuals - the "persuadable middle" - are frequently targeted in policy campaigns (Hillygus and Shields 2008). As suggested by the quotation above, undecided individuals 
play an influential role as voters in determining the outcome of ballot initiatives concerning same-sex marriage (Hogarth 2010). The same can be said of individuals with neutral opinions. Research has found that political campaigns generally have the greatest effect among select groups, including undecided voters (Hillygus and Jackman 2003). To better understand the complexity of opinions about same-sex marriage and to inform efforts to promote inclusive relationship recognition policies, we examine the characteristics of the "persuadable middle."

Younger generations tend to be more supportive of marriage equality than older cohorts (Lewis and Gossett 2008; Olson et al. 2006); thus younger adults are a potential allied group for advocates of same-sex marriage. However, scant research has focused on the attitudes of young people, such as college students.

Existing research demonstrates that reported rates of endorsement for same-sex marriage tend to be higher in college student samples than in samples of the general public. For example, $65 \%$ of the respondents in the 2010 American Freshman Survey supported same-sex marriage (Pryor et al. 2010); whereas a recent Gallop Poll found 53\% of Americans favor this policy option (Newport 2011). Additionally, college students elect a neutral or unsure response at much higher rates (between $15 \%$ and $21 \%$; Cluse-Tolar et al. 2005; Jenkins et al. 2007; Lannutti and Lachlan 2008; Swank and Raiz 2010) than the general public $(<5 \%$; see Avery et al. 2007; Brewer and Wilcox 2005), thereby indicating that college students, and younger generations more generally, may also be a particularly persuadable demographic group.

College students are also important to issues of same-sex relationship recognition because young adults often formulate their opinions about controversial social issues while attending college, and college has the potential to positively shape one's social attitudes on a host of issues, including gay rights (Ohlander et al. 2005). Additionally, college students are more likely to vote than their nonstudent peers (Highton and Wolfinger 2001). Moreover, adults with higher levels of education are more likely to vote than their peers with less education (Milligan et al. 2003; Powell 1986). As previous research has well established the connection between higher education and future socio-economic class (Baum and Payea 2004), college students' opinions are not only a reflection of current trends in attitudes; they can also be used to glean ideas about how attitudes might develop and evolve among privileged groups. With this information, advocates for same-sex marriage laws can better understand how to effect change in students' opinions and potentially public policy. This study's findings can also help social scientists better comprehend the unique and shared factors associated with differential stances (i.e., endorse, neutral, oppose) concerning marriage equality.

\section{Background}

\section{Same-Sex Marriage Policy}

In the USA, marriage offers important benefits and rights in areas such as healthcare, adoption, parenting, taxation, and finances (Woodford et al. 2011; Herdt and Kretzner 2006). Same-sex marriage policies provide gay and lesbian couples with the same rights, benefits, and obligations available to married opposite-sex partners. The current legal situation in the USA concerning recognition of same-sex relationships is complicated. The federal Defense of Marriage Act (DOMA) prohibits same-sex marriage and automatic or forced interstate recognition of legally recognized same-sex relationships treated as marriage (The Defense of Marriage Act 1996). However, at the time of writing, same-sex marriages are legally performed and recognized in Connecticut, District of Columbia, Iowa, Massachusetts, New Hampshire, New York, and Vermont, and Maryland recognizes same-sex marriages legally performed elsewhere (Human Rights Campaign 2011a).

Alongside federal legislation prohibiting same-sex marriage, 41 states have passed state-level versions of DOMA. Specifically, in 29 of these states, ballot initiatives codified constitutional prohibitions against same-sex marriage, whereas the legislatures in the remaining 12 states passed statutes defining marriage as between a man and a woman (Human Rights Campaign 2011b; National Gay and Lesbian Task Force 2010).

As history shows, at the state level, citizens have frequently determined gay and lesbian couples' relationship rights through direct democracy. Additionally, elected officials pay attention to, and act on, citizens' opinions as they create legislation (Burstein 1998). In both these circumstances, attitudes affect public policy. Therefore, understanding citizens' views about marriage equality is important and can inform efforts to build support for same-sex marriage.

\section{Opinions about Same-Sex Marriage}

Very few studies have exclusively examined college students' opinions about legally recognizing same-sex marriage. Survey items concerning same-sex marriage are sometimes used as part of studies exploring students' perceptions of gay men and lesbian women (Cluse-Tolar et al. 2005; Jenkins et al. 2007), gay rights (Raiz 2006), or general relationship rights for same-sex couples (Swank and Raiz 2010). Further, existing studies are limited as they engage only undergraduate students (Pryor et al. 2010) or survey only students within particular fields, such as social work (Raiz 2006; Swank and Raiz 2010) or communications (Lannutti and Lachlan 2008; Moskowitz et al. 2010). Thus, findings may have limited generalizability. In terms of predictors of student support for 
inclusive relationship policies, investigations have focused on same-sex marriage (Case and Stewart 2010; Knox and Zusman 2009; Lannutti and Lachlan 2008; Moskowitz et al. 2010) or general relationship rights for same-sex couples (Swank and Raiz 2010); however, very few employ multivariate analysis to identify covariates of support for inclusive policies.

A considerable gap exists in the current literature about the covariates of being part of the "persuadable middle" concerning same-sex marriage. Some studies do not include an undecided or neutral response option (e.g., Pryor et al. 2010; Olson et al. 2006), while others include such options but purposefully exclude respondents who selected these responses and examine endorsement as a dichotomous variable (endorsement versus opposition; e.g., Whitehead 2010). Other studies include a neutral response option, but examine endorsement as a continuous outcome (e.g., Knox and Zusman 2009; Sherkat et al. 2010). These methodological decisions mean that the factors associated with the "persuadable middle" are unknown.

Existing public opinion research indicates that women, White respondents, and younger persons tend to have more supportive views of same-sex marriage than men, people of color, and middle aged or older adults (Brumbaugh et al. 2008; Haider-Markel and Joslyn 2005; Lewis and Gossett 2008; Olson et al. 2006; Pearl and Galupo 2007). Among college students, results concerning race and gender have been inconsistent (Knox and Zusman 2009; Moskowitz et al. 2010; Swank and Raiz 2010). Studies conducted with members of the general public have also found religion to be influential. For example, studies have found that Christian respondents, specifically evangelical and conservative Protestant Christians tend to have significantly lower levels of support for same-sex marriage than non-Christians (HaiderMarkel and Joslyn 2008; Olson et al. 2006; Rowatt et al. 2009; Sherkat et al. 2010; Whitehead 2010). Similarly, those who consider religion to be important in their lives tend to hold less affirming opinions of same-sex marriage (HaiderMarkel and Joslyn 2005; Pearl and Galupo 2007). In terms of support for same-sex marriage, religious affiliation and the importance of religion in one's life (i.e., religiosity) have not been examined among college students.

Studies have also explored the role of attitudinal factors, namely political ideology, beliefs about the etiology of same-sex sexuality, and views toward gay and lesbian people, in shaping opinions about same-sex marriage policies. Among college studies, only the etiology of same-sex sexuality has been explored (Raiz 2006; Swank and Raiz 2010). Results suggest that those with liberal political views tend to support same-sex marriage more so than their conservative counterparts (Barth et al. 2009; Haider-Markel and Joslyn 2008; Olson et al. 2006; Rowatt et al. 2009; Sherkat et al. 2010; Whitehead 2010).
In the social sciences, etiologists are concerned with how individuals understand or explain the causes of behavior. Traditionally, behaviors are ascribed to either external or internal causes (Heider 1958). Genetics and other factors beyond the individual's control are examples of external causes; whereas, internal causes include personality and other variables within the individual's control and responsibility (Raiz 2006; Tygart 2000). Individuals who endorse external etiology of same-sex sexuality tend to see it as immutable; in contrast, those who support internal attributions generally believe that same-sex sexuality is a choice, and thus is changeable (Hegarty 2002; Raiz 2006). Endorsement of same-sex marriage policies tends to be linked to beliefs that same-sex sexuality is innate or biological (external), whereas those who believe it is an individual's choice (internal) tend to reject same-sex marriage policy (Haider-Markel and Joslyn 2008; Lewis 2009; Rowatt et al. 2009; Tygart 2000; Whitehead 2010). Similar results have been found among social work students in regard to endorsement for same-sex relationship rights (Swank and Raiz 2010) and gay rights (Raiz 2006).

Holding affirmative perceptions of gay and lesbian people has been found to be positively associated with endorsement for same-sex marriage (Lewis 2009; Rowatt et al. 2009). However, these studies have tended to examine only overt anti-gay biases, such as "homosexual conduct is morally wrong or sinful" (Lewis 2009), and have overlooked more subtle forms of prejudice, such as aversive heterosexism. Aversive heterosexism reflects beliefs such as gay and lesbian people are "too militant or receiving too much attention" (Walls 2008, p. 46). Given the often subtle and covert nature of homophobia today (Morrison and Morrison 2002; Nadal et al. 2010; Walls 2008), it is important to investigate the influence of subtle prejudices on support for same sex-marriage recognition laws.

Some researchers have examined the role of social context, such as an individual's contact with gay and lesbian people. Contact hypothesis posits that negative beliefs about stigmatized groups often lessen after personal contact with members of the stigmatized group (Allport 1954). Research conducted with the general public supports this hypothesis in that interpersonal contact with gay and lesbian people, particularly relevant and voluntary contact, are strong indicators of support for same-sex marriage (Barth et al. 2009). Swank and Raiz (2010) found that having gay and lesbian acquaintances increases the likelihood of students endorsing same-sex relationship rights.

Studies conducted with college students regarding their attitudes toward gay and lesbian people often investigate the role of exposure to educational content on sexual diversity (Finken 2002; Hinrichs and Rosenberg 2002; Rye and Meaney 2009). Research found that students taking part in diversity courses (women's studies) tend to support 
same-sex marriage more than students who participated in nondiversity courses (Case and Stewart 2010).

To advance understanding of the "persuadable middle," in this study we ask: what are the factors associated with differential views about same-sex marriage? Specifically, we sought to test the role of sociodemographics (age, sex, race/ethnicity, religious affiliation, and religiosity), political ideology, attitudes toward gay and lesbian people (malleability of same-sex sexuality, acceptability of same-sex relationships, and aversive heterosexism), social contact with sexual minorities, and exposure to educational content about sexual minorities to explore the nature of respondents who are "neutral" about same-sex marriage rather than endorsing or opposing this policy.

\section{Method}

Data for the current study are drawn from an online campus climate survey conducted among full- and part-time undergraduate and graduate students at a large public Research I university located in the Midwest. Students were invited to provide feedback about their perceptions of the campus climate, which was defined as "the actions and attitudes within a university that influence whether people feel welcomed and valued as members of the community." Part of the study investigated attitudes toward lesbian, gay, and bisexual (LGB) people, as well as toward same-sex marriage. To minimize participant self-selection, as suggested in the literature (Wiederman 2002), sexuality was not referenced in study recruitment or the informed consent materials. The survey was designed in consultation with an advisory board consisting of undergraduate and graduate students, alumni, staff, and faculty. The study received institutional review board approval.

The survey's format, interface, and distribution procedures mirrored those of the host institution's campus-wide student satisfaction and learning outcome surveys. Using official university email addresses, the registrar's office contacted students three times. First, an invitation to join the study was distributed which included a link to the survey website. Two reminder emails, which also included the link to the survey, were sent 7 and 14 days after the initial email. All participants were offered an opportunity to enter a raffle for one of fifty $\$ 50$ cash cards.

\section{Sample}

The sample for the current analysis was drawn from a census of both sophomore and junior undergraduates $(N=$ 11,342 ) plus a random sample of 8,000 graduate students. Just over 5,000 students activated the survey link. As is common with anonymous internet-based surveys (Dillman et al. 2009; The American Association for Public Opinion Research 2011), we are unable to determine if the students who did not activate the survey link received the email invitation/reminder emails or if they were not interested in joining the study. Although we used official university email addresses, it is possible that some students may not use their university account or check it infrequently. Out of those who activated the survey link, 3,762 agreed to participate; however, 733 students provided partial answers (i.e., did not answer key questions) and 761 did not answer any questions, thereby reducing the sample to 2,268. A comparison of the demographics of the final sample and those eliminated from the sample due to missing data showed that these groups are similar, with the exception of sex, $\chi^{2}(2)=16.55, p<.001$ (final sample $39.2 \%$ male; partial data sample $46.5 \%$ male). Based on the number of students invited to participate in the study, the response rate is $11.7 \%$ and based on those known to have received the survey, the response rate is $45.1 \%$.

In our analysis, we follow Herek's (1988) suggestion that researchers examine the attitudes of heterosexuals and sexual minorities separately since predictor variables likely operate differently for each group. For this study, the sample is limited to heterosexual students who are US citizens $(n=$ 1,703). The sample characteristics are reported in Table 1. Age ranged from 18 to 60 with a mean of $22.80(S D=5.92)$. Half of the sample was 20 years of age or less. The sample had more female respondents $(62.1 \%)$ than male and consisted predominately of full-time students $(95.2 \%)$ pursuing an undergraduate degree $(61.8 \%)$. Most of the sample identified as White $(80.1 \%)$ and reported being affiliated with a Christian religion $(77.6 \%)$ with an overall low level of religiosity.

Outcome Variable The outcome variable for this study was endorsement of same-sex marriage, which was assessed with the following survey item: "Marriage should be equally available to both heterosexual and same-sex couples." The item was originally scored using a 7-point Likert scale ( $1=$ strongly disagree, $4=$ neutral, $7=$ strongly agree). Given our interest in understanding the "persuadable middle," we collapsed response options to create three qualitatively distinct groups: "endorse" (slightly agreestrongly agree), "persuadable middle" (neutral), and "oppose" (strongly disagree-slightly disagree). In this study, we viewed this as an unordered categorical outcome because of our empirical interest in the "persuadable middle."

Independent Variables Demographic variables included age, sex, race/ethnicity, religious affiliation, and religiosity. Religiosity was measured via the question: "How important is religion to you?" ( $1=$ not at all important, $4=$ very important $)$. Political ideology was indicated using a 7-point Likert scale $(1=$ extremely conservative, $7=$ extremely liberal $)$. 
Table 1 Descriptive statistics for sample and study variables

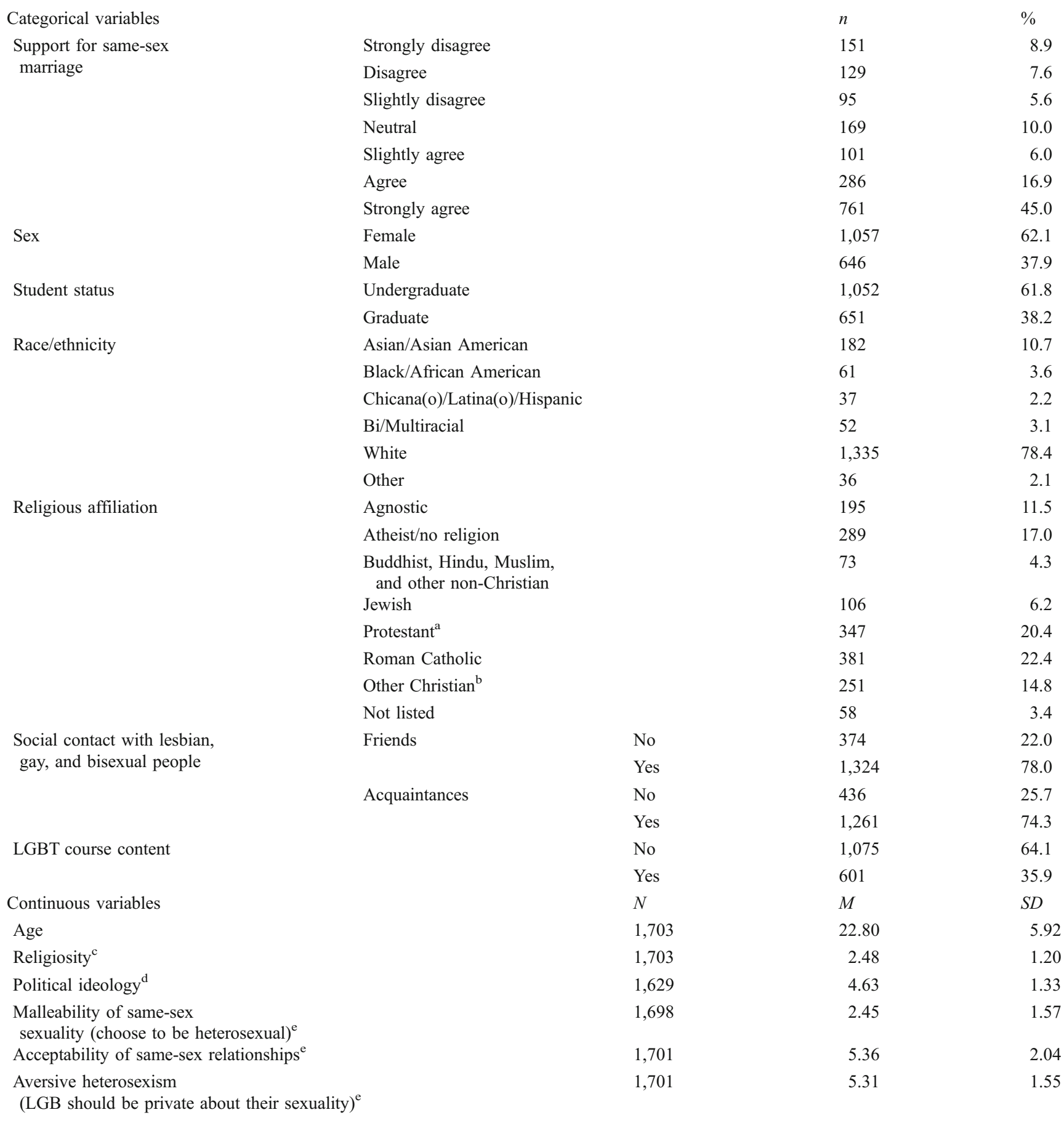

$L G B T$ Lesbian, gay, bisexual, and transgender

${ }^{a}$ Baptist, Church of Christ, Episcopalian, Lutheran, Methodist, Presbyterian, and United Church of Christ

${ }^{\mathrm{b}}$ Eastern Orthodox, Church of the Latter Day Saints (Mormon), Quaker, Seventh Day Adventist, and other Christian

${ }^{\mathrm{c}} 1=$ Not at all important, $4=$ very important

${ }^{\mathrm{d}} 1=$ Extremely conservative, $7=$ extremely liberal

${ }^{\mathrm{e}} 1=$ Strongly disagree, $7=$ strongly agree

Concerning views about same-sex sexuality, we posed three questions: (1) the malleability of same-sex sexuality,
"Lesbians and gay men could be heterosexual if they really wanted to be;" (2) acceptability of same-sex relationships, 
"It is perfectly okay for people to have intimate relationships with people of the same sex;" and (3) aversive heterosexism, "Lesbian, gay, and bisexual people should be private about their sexual orientation." Each question utilized a 7-point Likert scale (1=strongly disagree, $7=$ strongly agree).

We included two social context variables. Specifically, we asked respondents if they had LGB friends, and if they had LGB acquaintances. We also asked if the respondent had taken any for-credit courses at the host institution or elsewhere with content on the lesbian, gay, bisexual, and/or transgender (LGBT) community. Each of these variables was coded no/yes.

\section{Data Analysis}

We used Predictive Analytics Software 17.0 for analysis. We conducted descriptive analyses for all variables. Before undertaking multivariate analyses, we examined the correlation matrix to assess for multicollinearity and detected no problems. We used multivariate regression procedures to identify factors associated with endorsement of same-sex marriage while controlling for potentially confounding variables. The specific procedure used was multivariate multinomial logistic regression, which is used for unordered categorical data. This procedure was selected because our three-level outcome failed to meet the restrictive assumptions for an ordinal regression. Moreover, ordinal regression would not enable us to identify the characteristics specific to the "persuadable middle" because a reference group is not assigned. Similar to binary logistic regression, multinomial logistic regression requires the parameter estimates be interpreted relative to a reference group. We specified the neutral category as the reference group. Thus, two separate sets of parameter estimates are produced that reflect the odds endorsing or opposing same-sex marriage relative to being neutral. It should be noted that, because these are unordered outcomes, we are unable to make interpretations regarding differences in the amount of support among the categories. For this study, we discuss the results in regard to the odds of being neutral versus supporting or opposing same-sex marriage.

\section{Results}

Table 1 presents descriptive statistics for all variables included in the study. Overall, the sample was generally supportive of same-sex marriage $(M=5.27, S D=2.08)$, but not overly so. More respondents indicated agreement (slightly to strongly; 67.9\%) than disagreement (slightly to strongly; 22.1\%). Accordingly, $10.0 \%$ of the sample reported neutral for same-sex marriage.
Predictors of Attitudes toward Same-Sex Marriage

A test of the model against the constant was statistically significant, $\chi^{2}(44)=1185.07, p<.001$, with a Nagelkerke $R^{2}$ of 0.66 , which indicates a large effect size. Table 2 presents the multivariate regression results.

Endorsement for Same-Sex Marriage Contrasting students with a neutral opinion with those who agreed with samesex marriage, most of our predictors were significant (race/ ethnicity, religion, religiosity, political ideology, malleability of same-sex sexuality, acceptability of intimate same-sex relationships, aversive heterosexism, and exposure to a course with LGBT content). In terms of race/ethnicity, respondents who identified as Black/African American $(\mathrm{AOR}=0.18,95 \%$ CI $0.08,0.44)$ or Chicana(o)/Latina(o)/ Hispanic (AOR $=0.23,95 \%$ CI 0.07, 0.73) had higher odds of reporting neutral rather than endorsing same-sex marriage than their White counterparts. No other race/ethnicity categories were significantly different from the reference group.

Concerning religious affiliation, Atheist respondents or those with no religion were found to have higher odds of holding neutral views about this policy than Jewish students $(\mathrm{AOR}=7.97,95 \%$ CI $1.50,42.47)$. All other religious affiliation groups were not statistically different from the reference category. Students who reported higher levels of religiosity had increased odds of selecting neutral (AOR $=0.62,95 \%$ CI $0.46,0.84)$.

Increases in liberal political ideology $(\mathrm{AOR}=1.69,95 \%$ CI $1.40,2.04)$ and views about the acceptability of samesex relationships $(\mathrm{AOR}=1.46,95 \%$ CI $1.28,1.67)$ were each associated with decreased odds of being neutral toward same-sex marriage. Increases in aversive heterosexism (AOR $=0.73,95 \%$ CI $0.62,0.85)$ were associated with increased odds of neutral views about same-sex marriage. Students who reported exposure to LGBT content in courses (AOR $=1.71,95 \%$ CI 1.07, 2.74) had lower odds of being neutral toward the outcome than those who have not had such content.

Opposition to Same-Sex Marriage In comparison to those who opposed same-sex marriage, for respondents with neutral opinions, significant predictors included: political ideology, malleability of same-sex sexuality, and acceptability of same-sex relationships. Specifically, as political ideology became more liberal $(\mathrm{AOR}=0.75,95 \%$ CI 0.61 , 0.92 ) and attitudes about the acceptability of same-sex relationships (AOR $=0.70,95 \%$ CI $0.61,0.79$ ) became more affirming, the odds of holding neutral opinions about same-sex marriage versus opposing it increased. In contrast, increases in considering same-sex sexual orientation as changeable $(\mathrm{AOR}=1.20,95 \% \mathrm{CI} 1.03,1.41)$ were associated 
Table 2 Multinomial logistic regression predicting endorsement and opposition to same-sex marriage $(n=1,579)$ ref Reference category; $A O R$ adjusted odds ratio; $C I$ confidence interval; $L G B$ lesbian, gay, and bisexual; $L G B T$ Lesbian, gay, bisexual, and transgender; bold indicates statistical significance

${ }^{\text {a}}$ Reference category: neutral ${ }^{\mathrm{b}}$ Higher number indicates greater level of religiosity (range 1-4)

${ }^{\mathrm{c}}$ Higher number indicates more liberal (range 1-7)

${ }^{\mathrm{d}}$ Higher number indicates more agreement (range 1-7)

\begin{tabular}{|c|c|c|}
\hline \multirow[b]{3}{*}{ Variable } & \multicolumn{2}{|l|}{ Same-sex marriage } \\
\hline & \multirow{2}{*}{$\frac{\text { Endorse }^{\mathrm{a}}}{\text { AOR }(95 \% \mathrm{CI})}$} & \multirow{2}{*}{$\frac{\text { Oppose }^{\mathrm{a}}}{\text { AOR }(95 \% \text { CI })}$} \\
\hline & & \\
\hline \multicolumn{3}{|l|}{ Demographics } \\
\hline Age in years & $1.02(0.98,1.05)$ & $1.04(1.00,1.08)$ \\
\hline Sex (ref. male) & $1.13(0.74,1.74)$ & $1.16(0.73,1.83)$ \\
\hline \multicolumn{3}{|l|}{ Race/ethnicity (ref. White) } \\
\hline Asian/Asian American & $0.55(0.29,1.03)$ & $0.76(0.38,1.48)$ \\
\hline Bi/Multiracial & $1.13(0.36,3.62)$ & $0.67(0.17,2.72)$ \\
\hline Black/African American & $0.18(0.08,0.44)$ & $0.59(0.25,1.40)$ \\
\hline Chicana(o)/Latina(o)/Hispanic & $0.23(0.07,0.73)$ & $0.47(0.13,1.67)$ \\
\hline Other & $3.17(0.61,16.44)$ & $1.05(0.19,5.99)$ \\
\hline \multicolumn{3}{|l|}{ Religion (ref. atheist/no religion) } \\
\hline Agnostic & $0.80(0.35,1.84)$ & $0.59(0.20,1.78)$ \\
\hline Buddhist, Hindu, Muslim, and other non-Christian & $3.21(0.88,11.74)$ & $0.27(0.06,1.26)$ \\
\hline Jewish & $7.97(1.50,42.47)$ & $1.07(0.15,7.84)$ \\
\hline Protestant & $1.95(0.76,4.96)$ & $0.58(0.20,1.70)$ \\
\hline Roman Catholic & $1.98(0.78,5.01)$ & $0.51(0.17,1.54)$ \\
\hline Other Christian & $1.22(0.45,3.31)$ & $0.50(0.16,1.56)$ \\
\hline Not listed & $5.13(0.84,31.38)$ & $1.45(0.22,9.61)$ \\
\hline Religiosity $^{\mathrm{b}}$ & $0.62(0.46,0.84)$ & $1.17(0.85,1.62)$ \\
\hline \multicolumn{3}{|l|}{ Attitudinal factors } \\
\hline Political ideology ${ }^{\mathrm{c}}$ & $1.69(1.40,2.04)$ & $0.75(0.61,0.92)$ \\
\hline Malleability of same-sex sexuality ${ }^{\mathrm{d}}$ & $0.86(0.73,1.01)$ & $1.20(1.03,1.41)$ \\
\hline Acceptability of same-sex relationships ${ }^{\mathrm{d}}$ & $1.46(1.28,1.67)$ & $0.70(0.61,0.79)$ \\
\hline Aversive heterosexism ${ }^{c}$ & $0.73(0.62,0.85)$ & $1.07(0.91,1.26)$ \\
\hline \multicolumn{3}{|l|}{ Contextual factors (ref. no) } \\
\hline LGB friends & $1.06(0.67,1.70)$ & $0.99(0.62,1.60)$ \\
\hline LGB acquaintances & $1.21(0.79,1.88)$ & $1.25(0.78,1.99)$ \\
\hline \multicolumn{3}{|l|}{ Educational factor (ref. no) } \\
\hline Course with LGBT content & $1.71(1.07,2.74)$ & $1.09(0.65,1.80)$ \\
\hline
\end{tabular}

with decreases in the odds of being neutral about same-sex marriage. All other variables were not significantly associated with the outcome.

\section{Discussion}

The legal recognition of same-sex relationships has important social policy implications for gay and lesbian couples. Identifying those who are neutral in their views and attempting to persuade them to adopt your particular group's position is a basic objective of policy advocacy and community organization (Kaminski and Walmsley 1995; Lee 2011). Although considerable research examines opinions toward same-sex marriage, individuals who are undecided or neutral in their views have been essentially overlooked. This study represents one of the first to examine factors associated with neutral stances on samesex marriage.

Overall, we find high levels of endorsement among our sample for same-sex marriage at rates considerably higher than those documented among the general public. Compared to previous studies conducted with college students (except the most recent American Freshman Survey; Pryor et al. 2010), we find a noticeably higher rate of support for same-sex marriage among our participants. Concomitantly, the percentages of neutral and negative responses in our sample were lower than in previous research (Cluse-Tolar et al. 2005; Jenkins et al. 2007; Lannutti and Lachlan 2008; Raiz 2006; Swank and Raiz 2010); however, they remain sizeable (neutral, $10.0 \%$; oppose, $22.1 \%$ ). 
The continuously growing discourse about same-sex marriage may help to explain the difference between our findings and those of earlier studies. National media attention given to California's Proposition 8 and samesex marriage during the 2008 presidential elections may have played an influential role. Our survey was conducted approximately 4 months after these events, thus respondents may have developed a heightened awareness of the issues surrounding same-sex marriage. Furthermore, existing studies have engaged only undergraduate students (Cluse-Tolar et al. 2005; Jenkins et al. 2007; Lannutti and Lachlan 2008; Swank and Raiz 2010), whereas we include both undergraduate and graduate students. It is possible that being enrolled in graduate education may contribute to more supportive views about same-sex marriage.

\section{Characteristics of the "Persuadable Middle"}

We found considerable diversity in terms of the factors associated with being neutral versus either endorsing or opposing same-sex marriage. In multivariate analysis, eight factors were significant in endorsing same-sex marriage, whereas only three were significant in opposing it. Only two variables, namely political ideology and views about the acceptability of same-sex relationships, were significant for both endorsement and opposition. The significance of these two variables suggests that one's overall political views and perceptions about the acceptability of same-sex relationships actively affect one's views of same-sex marriage generally (i.e., across endorsement and opposition) even when controlling for other related variables. These two variables therefore have important implications for efforts to advance same-sex marriage laws. We discuss these and other noteworthy findings below.

Attitudinal Factors When endorsing same-sex marriage, the "persuadable middle" participants tend to have more conservative political views and less accepting views of same-sex relationships than those who supported same-sex marriage. However, these same neutral respondents tend to be more politically liberal and view same-sex relationships as more acceptable than those who opposed same-sex marriage. These documented relationships are not surprising given the positive relationships found in earlier research between support for same-sex marriage and liberal political ideology (Brumbaugh et al. 2008; Rowatt et al. 2009; Tygart 2002), and also positive views about gay and lesbian people (Lewis 2009; Rowatt et al. 2009).

Our findings about the role of aversive heterosexism and one's stance toward same-sex marriage are intriguing and make a unique contribution to the field. Previous research has not examined the role of subtle antigay biases and inclusive relationship recognition policies. The "persuadable middle" in endorsement for same-sex marriage tend to be students who more strongly affirmed the statement that LGB people should be quiet about their sexuality. This variable was not significant in regard to opposing same-sex marriage, which may be due to the fact that political ideology, acceptability of same-sex relationships, and other attitudinal variables were controlled. Our findings suggest that the subtle forms of heterosexism that pervade society may lead some students to be part of the "persuadable middle" rather than supporting same-sex marriage. Interestingly, our results also suggest that aversive heterosexism may not translate into active opposition for same-sex marriage, but rather that opinions about the acceptability of same-sex relationships and political views play a powerful role in that opposition.

Aversive heterosexism reflects the belief that gay and lesbian people are seeking too many rights or wanting too much attention in contemporary society (Walls 2008). Expecting LGB people to be quiet about their sexuality is a component of aversive heterosexism, therefore it is possible that students who endorse this statement believe that marriage is one of the "too many rights" or "too much attention" inherent in aversive heterosexism. Students who are more politically conservative (Morrison and Morrison 2002; Walls 2008), do not support rights for any minority group or feel threatened by same-sex sexuality may be especially likely to embrace such thinking. Additionally, some students who believe gay and lesbian people are seeking "too many rights" may not understand the importance of such rights, including those only available through legal marriage. Such a lack of understanding is a component of heterosexual privilege.

Although we use the statement about LGB people being quiet about their sexuality as an indicator of aversive heterosexism, it is possible that some students may interpret it in other ways. For example, some may agree with the statement because they are uncomfortable talking about sexuality, generally, or same-sex sexuality, specifically. In both cases, same-sex marriage involves a public acknowledgement of sex. We wonder if some individuals who are uncomfortable talking about samesex sexuality might believe that "it is okay to be gay or lesbian, but don't talk about it," and that same-sex marriage represents an overt form of "talking about it." Although perceptions are changing, such norms have been documented in some racial/ethnic minority communities (Akerlund and Cheung 2000; Greene and BoydFranklin 1996; Morales 1992; Parks 2010). Additional research is needed to examine these possible interactions and it will be useful to explore the role of different aspects of aversive heterosexism. 
Existing research indicates that believing same-sex sexuality is a choice is associated with opposition toward inclusive relationship policy (Haider-Markel and Joslyn 2005; Swank and Raiz 2010). In this study, we did not measure etiology of same-sex sexuality; rather, we assessed the malleability of same-sex sexuality. Although these concepts are not equivalent, research suggests that they are strongly connected as individuals who see sexuality as biologically determined also tend to see sexuality as immutable and outside the individual's control (Hegarty 2002; Raiz 2006).

The malleability variable was only significant in terms of opposing same-sex marriage, where the "persuadable middle" tend to have lower levels of agreement with the assertion that gay men and lesbians could choose to be heterosexual. Perhaps supporters of same-sex marriage may qualitatively differ in their reasons for taking a positive position. Some individuals may support relationship policy changes that would include same-sex relationships regardless of their beliefs about the mutability of same-sex sexuality. Among these individuals, some may conceptualize sexuality as a fluid identity that is profoundly influenced by social context (Peplau and Garnets 2000; Savin-Williams and Diamond 2000), and thus believe marriage should be available to all. In contrast, those upholding the notion that gay and lesbian people could choose to be heterosexual may see this as cause to reject same-sex marriage, believing instead that one should "choose" to be straight if marriage is the goal. It will be important for future research to investigate these propositions.

Contextual Factors and Education The findings concerning the contextual factors and the course content variable present valuable information in our understanding of the "persuadable middle." First, it is quite remarkable that both LGB contact variables were not significant in the model given the positive associations found in previous studies (Barth et al. 2009; Swank and Raiz 2010). As younger cohort's attitudes toward sexual minorities generally continue to become more accepting and as more LGB students choose to disclose their sexual orientation, including at increasingly younger ages, the majority of today's college students likely have some level of contact with LGB people; thus, the effect size of contact variables may not be detected due to the small number of students who report no contact and the influence of other variables controlled for in the model. An overwhelming majority of our participants reported having LGB friends $(78.0 \%)$ and LGB acquaintances $(74.3 \%)$. Results may be different among participants who have less contact with LGB people.

It is also possible that although contact with LGB people may facilitate acceptance of LGB individuals (Basow and
Johnson 2000; Hinrichs and Rosenberg 2002), these effects may not extend to opinions toward same-sex marriage among college students. The average LGB college student may not see same-sex marriage to be an important topic in their daily lives, especially given current life stage stressors, such as coping with academic pressures and possibly LGB specific issues, such as coming out or heterosexist harassment (Rankin 2003). If same-sex marriage is not important to them, the topic is likely not part of their everyday conversations with their peers-heterosexual or otherwise; as a result, the opportunity to influence others' views about same-sex marriage is missed. However, we wonder if the social justice education pedagogy inter-group dialogue (Dessel et al. 2011), which is based on contact theory, would positively affect heterosexual students' views about this policy if same-sex marriage were a planned discussion topic.

Interestingly, course work with LGBT content was significant only regarding endorsement of same-sex marriage. Here, students who do not encounter LGBT content in their courses are at increased odds of being part of the "persuadable middle." Thus, our results broadly suggest that exposure to LGBT content can directly or indirectly influence a student with neutral views to shift positions and endorse same-sex marriage. Although this is a promising finding for same-sex marriage advocates, we offer this interpretation with caution. It is possible that those who support same-sex marriage were already predisposed to take a course with LGBT content and this may account for the variable's significance. Additional research into this area is warranted to examine the myriad factors at play. It will also be important to examine the nature of the content discussed; for example, was content on same-sex marriage or related curriculum covered? Or were other LGBT-related topics addressed, such as the etiology of same-sex sexuality, and if so did these influence respondents' endorsement of same-sex marriage?

Demographics Among significant predictors, no consistent trends are observable across the two sets of parameter estimates. Yet, the findings highlight that certain demographic groups may be more likely to be members of the "persuadable middle," specifically with regard to endorsing same-sex marriage. We found Black/African American, Chicana(o)/ Latina(o)/Hispanic students, and those with high religiosity in their lives were more likely than White students and those who place lower value on religion to be associated with a neutral view of same sex-marriage. Given the low number of Black/African American and Chicana(o)/Latina(o)/Hispanic respondents, we offer our interpretations with considerable care. Earlier public opinion research found these groups to be opposed to same-sex marriage (Brumbaugh et al. 2008; Olson et al. 2006; Rowatt et al. 2009); however, in the current 
study, these variables are not significant in opposing the policy. This may be partially accounted for because our sample consists of college students - individuals who are exposed to a range of diverse groups and ideas, who are often encouraged to engage in critical thinking and many of whom are developing their own perspectives on complicated social issues (Arnett and Jensen 2002; Ohlander et al. 2005). These factors may produce a reluctance to reject inclusive policies for any group.

Norms of silence or secrecy around same-sex sexuality and same-sex relationships exist in some racial/ethnic minority communities (Akerlund and Cheung 2000; Greene and Boyd-Franklin 1996; Mason 2009; Morales 1992; Parks 2010). In many of these communities, religion may play a central role in creating and maintaining these norms (Greene and Boyd-Franklin 1996; Parks 2010). However, the differences that emerge in the analysis between racial/ ethnic groups cannot be attributed to religious affiliation and religiosity since those factors are controlled for in the model. Therefore, another aspect of religion, such as an individual's everyday theologies (Moon 2004), not accounted for in this model may be at the root of the differences that emerge. Such factors may help to explain our findings concerning Black/African American and Chicana(o)/Latina (o)/Hispanic students, as some members of these communities, especially college students, may face an internal tension between their (developing) personal beliefs and cultural and religious norms about sexual minorities and same-sex marriage, and thus selected neutral. Although racial/ethnic minority individuals may not want to deny general civil rights to same-sex couples (Lewis 2003), they may be equally uncomfortable explicitly endorsing policy that would legitimize same-sex relationships (Parks 2010). Additional research is needed to explore these dynamics. It will be important to examine the interaction between race/ethnicity and religion, and to document the relationship between church doctrine and personal beliefs about these teachings (Walls 2010).

We found atheist/no religion respondents have higher odds of being part of the "persuadable middle" rather than endorsing same-sex marriage, compared to Jewish students. In light of the low number of Jewish respondents, we interpret this finding with prudence. Perhaps Jewish students who completed the survey belong to liberal segments of the Jewish religion or hold political views that promote inclusivity toward gay and lesbian people. Studies have found that Jewish people tend to be very politically liberal (Green 2004; Kotler-Berkowitz 2005). As well, research has found Jewish respondents to be less prejudicial toward gay and lesbian individuals than respondents from other religions and those reporting no religious preference (Bolzendahl and Brooks 2005; Fisher et al. 1994). Additional research is needed to examine these factors.
Given the results of previous studies concerning religious affiliation, we were somewhat surprised to find only the comparisons with Jewish participants to be significant. However, religion, especially organized religion, generally does not play a significant role in the lives of young adults and the personal beliefs of young people often diverge from institutionalized church teachings (Arnett and Jensen 2002). As young adults, college students tend to be developing their religious identities, and thus may not fully embrace any one religious doctrine (Fowler 1981). Furthermore, just because an individual identifies with a particular religious affiliation does not mean he or she agrees with its teachings about same-sex sexuality and same-sex marriage (Arnett and Jensen 2002; Walls 2010). On the other hand, some of our respondents who identified with Protestant traditions or other Christian affiliations may attend congregations that are affirming of same-sex sexuality, which could account for the insignficant findings. To fully understand the relationship between religious affiliation and support for same-sex marriage, research that examines the messages posited within particular denominations and the extent to which participants endorse these messages is necessary (Walls 2010). Future studies should examine these relationships.

\section{Limitations}

This study offers important insights into the complex nature of perceptions about same-sex marriage. Nonetheless, noteworthy limitations exist, some of which suggest directions for future research. First, cross-sectional research has the inherent problem of temporal ordering, thus causality cannot be determined. Second, the results may be only generalizable to other institutions with similar student demographics. Third, the study's response rate is low, however it is comparable to those of campus-wide learning outcome and satisfaction surveys conducted at the host institution $(\sim 10 \%)$ and response rates for other long online surveys (15.1\%; Yetter and Capaccioli 2010). As indicated, we were unable to determine if all individuals selected to be in the study received the invitation/reminder emails; however, among those known to receive the survey, we achieved an acceptable response rate for an online survey. Differences between respondents and nonrespondents may exist, but our anonymous design prohibits us from exploring these. However, given that the stated purpose of the study did not reference attitudes toward lesbians and gay men, it is unlikely that students who harbor extreme antigay biases declined to participate in the survey solely for this reason. Also, a number of students prematurely ended their participation, which in turn, decreased the overall sample size for our current analysis. Fourth, concerns exist about the representativeness of the sample because the percentages of males, graduate students, and African 
Americans were lower in the original sample compared to the host university's overall rates. It is impossible to assess representativeness based on sexuality because the university does not collect this information. Fifth, although participant anonymity provided some protection against social desirability, our study would have been strengthened with the inclusion of a social desirability scale.

Sixth, the use of author-created single-item indicators for antigay bias may be an additional limitation. Although large-scale public opinion surveys on the topic often use single-item measures of attitudes toward gay and lesbian people (Haider-Markel and Joslyn 2008; Lewis 2009; Rowatt et al. 2009), using a single item instead of a summative score of an entire scale can offer limited variability. Future investigations may look to use full scales to garner greater understanding of how different types of beliefs about gay and lesbian people may be related to participants' support for legal recognition of same-sex relationships.

Finally, our grouping of Protestant religions into one category prevents us from capturing nuances across this broad group of religious affiliations, including some that may be affirming toward same-sex couples (Buzzell 2001). The core concern with religion may not be religious affiliation, but adherence to fundamentalist religious views (Fulton et al. 1999). It will be important to examine these relationships in future studies

\section{Conclusions and Implications}

The literature offers insights into the factors linked to levels of support for legal recognition of same-sex relationships, especially marriage. However, existing studies do not shed light on the characteristics of those who hold neutral views in comparison to those who are supportive of or opposed to same-sex marriage. In addition to advancing social science knowledge about the complexity of attitudes toward samesex marriage, understanding the variables that contribute to being part of the "persuadable middle" concerning this policy can provide empirical evidence to promote inclusive relationship laws. Engaging college students in this regard is especially worthwhile given previous research documenting high levels of endorsement among this population and the fact that many people formulate their opinions about controversial social issues while in college.

Given that political ideology was significant across both of our models, it can be surmised that those who report neutrality about same-sex marriage are those who are moderate in their political beliefs. This is a specific group that is often targeted during elections through use of popular swing issues, with same-sex marriage being one such issue (Hillygus and Shields 2008). Campaign efforts may need to demonstrate how the passing of inclusive policy does not take away from heterosexuals in any way and does not impact one's life either way. This is not meant to downplay the significance that such a policy change would have for countless gay and lesbian couples who seek to marry, but rather a political strategy geared toward those who have not yet formed their opinion about same-sex marriage. Campaigns that highlight personal stories about the importance of same-sex marriage to real-life same-sex couples have been shown to demonstrate positive results in this regard (Barth and Parry 2009).

The importance of fostering accepting attitudes about same-sex relationships cannot be underestimated. Our findings suggest that same-sex marriage campaigns that focus on same-sex couples without reference to marriage may be useful in promoting support for same-sex marriage. Campaigns that specifically highlight parallels between heterosexual couples and same-sex couples may encourage acceptance of same-sex relationships and potentially samesex marriage. Here, however we guard against presenting same-sex couples as just the same as heterosexual couples; we believe it will be important to represent some of the unique strengths of gay and lesbian couples in such campaigns (see Biblarz and Savci 2010).

Current campus-based awareness initiatives, including speaker panels and ally training programs, may help to foster acceptance of same-sex relationships. However, for these programs to be most useful in this regard, it will be important that their content include discussion of same-sex relationships versus simply talking about LGB people as individuals. These programs tend to focus on the experiences and needs of individuals, specifically college-age related experiences and needs, such as coming out, types of heterosexist harassment, and how to support an LGB student (Draughn et al. 2002; Lucksted 1998; Span 2001; Woodford et al. 2011), thus these programs tend not to discuss gay and lesbian relationships per se. Integrating content on same-sex couples will be important if the potential of these campus awareness programs to contribute to endorsement of samesex marriage is maximized. It is possible that such content may help to sway students in the "persuadable middle" to become allies for inclusive relationship laws.

Our findings also imply that it will be important to address the perspective that gay and lesbian people should be quiet about their sexuality. Educational interventions that foster students' understanding of the importance of minority rights, generally, and the significance of the legal benefits of marriage, in particular, are recommended. Also, interventions that highlight the cost of being closeted about one's minority sexuality (see Herek and Garnets 2007) may be useful in helping students who endorse this form of subtle heterosexism to understand the importance of LGB people being open about their sexuality. Given cultural norms promoting silence about same-sex sexuality in some racial minority communities 
(Akerlund and Cheung 2000; Greene and Boyd-Franklin 1996; Mason 2009; Morales 1992; Parks 2010), it will also be important to engage individuals from these communities in developing culturally competent intervention strategies.

Although demographic factors overall played a minimal role in our findings, we did find that Black/African American or Chicana(o)/Latina(o)/Hispanic and those who place high value on religion in their lives have higher odds of being part of the "persuadable middle" (than endorse same-sex marriage). Additionally, students who are atheist or do not have a religious affiliation were found to have higher odds of being part of the neutral group than support same-sex marriage compared to their Jewish peers. Purposeful outreach to students who are a part of these particular identity groups or who consider religion to be important in their lives may help to foster allies for samesex marriage. It may be helpful to identify individualsespecially those in leadership roles who embrace marriage equality - to collaborate on the development of culturally competent policy campaigns. Formative research through community conversations, focus groups, and key informant interviews will likely be useful for this purpose. It will be important to share the results and the developed strategies with the broader social policy community.

This study represents a first step in achieving a better understanding about the "persuadable middle." Further research should seek to expand this knowledge base and advance the depth of the factors that play a role on various stances toward other civil rights issues. Moreover, future studies should examine the factors associated with being a swing voter (i.e., having a position, but a position that can change). Targeted efforts, including educational endeavors and media campaigns, may help to persuade those voters in the middle toward a significant paradigm shift that would benefit all individuals and families in important ways.

Acknowledgments This study was financially supported by the National Center on Institutional Diversity, University of Michigan; the Office of Vice President for Research, University of Michigan; and the Curtis Center, School of Social Work, University of Michigan. Sincere thanks to the study advisory committee and participants. We also thank the anonymous peer reviewers for their helpful comments. This article was made available as Open Access with the support of the University of Michigan COPE Fund, http://lib.umich.edu/cope.

\section{References}

Akerlund, M., \& Cheung, M. (2000). Teaching beyond the deficit model: gay and lesbian issues among African Americans, Latinos, and Asian Americans. Journal of Social Work Education, 36, 279-292.

Allport, G. W. (1954). The nature of prejudice. Cambridge: AddisonWesley.

American Association for Public Opinion Research, The (2011). Standard definitions: Final dispositions of case codes and outcome rates for surveys (7th ed.). AAPOR. Retrieved September 25, 2011, from http://www.aapor.org/AM/Template.cfm? Section $=$ Standard_Definitions $2 \&$ Template $=/ \mathrm{CM} /$ ContentDisplay. cfm\&ContentID $=3156$.

Arnett, J. J., \& Jensen, L. A. (2002). A congregation of one: individualized religious beliefs among emerging adults. Journal of Adolescent Research, 17, 451-467. doi:10.1177/0743558402175002.

Avery, A., Chase, J., Johansson, L., Litvak, S., Montero, D., \& Wydra, W. (2007). America's changing attitudes toward homosexuality, civil unions, and same-gender marriage: 1977-2004. Social Work, 52, 71-79.

Barth, J., \& Parry, J. (2009). The impact of contact with gay and lesbian couples on attitudes about gays/lesbians and gay-related policies. Politics \& Policy, 37, 31-50. doi:10.1111/j.17471346.2007.00160.x.

Barth, J., Overby, L. M., \& Huffmon, S. H. (2009). Community context, personal contact, and support for an anti-gay rights referendum. Political Research Quarterly, 62, 355-365. doi:10.1177/1065912908317033.

Basow, S., \& Johnson, K. (2000). Predictors of homophobia in female college students. Sex Roles, 42, 391-404. doi:10.1023/ A:1007098221316.

Baum, G., \& Payea, K. (2004). Education pays 2004: the benefits of higher education for individuals and society. Washington: College Board.

Biblarz, T. J., \& Savci, E. (2010). Lesbian, gay, bisexual and transgender families. Journal of Marriage and Family, 72, 480 497. doi:10.1111/j.1741-3737.2010.00714.x.

Bolzendahl, C., \& Brooks, C. (2005). Polarization, secularization, or differences as usual? The denominational cleavage in U.S. social attitudes since the 1970s. The Sociological Quarterly, 46(1), 4778. doi:10.1111/j.1533-8525.2005.00004.x.

Brewer, P. R., \& Wilcox, C. (2005). The polls-trends: same-sex marriage and civil unions. Public Opinion Quarterly, 69, 599616. doi:10.1093/poq/nfi052.

Brumbaugh, S. M., Sanchez, L. A., Nock, S. L., \& Wright, J. D. (2008). Attitudes toward same-sex marriage in states undergoing marriage law transformation. Journal of Marriage and Family, 70, 345-359. doi:10.1111/j.1741-3737.2008.00486.x.

Burstein, P. (1998). Bringing the public back in: should sociologists consider the impact of public opinion on public policy? Social Forces, 77, 27-62. doi:10.2307/3006009.

Buzzell, T. (2001). Gay and lesbian activism in American Protestant churches: religion, homosexuality, and the politics of inclusion. In B. A. Dobratz, L. K. Waldner, \& T. Buzzell (Eds.), The politics of social inequality (pp. 83-114). Bingley: Emerald Group.

Case, K., \& Stewart, B. (2010). Changes in diversity course student prejudice and attitudes toward heterosexual privilege and samesex marriage. Teaching of Psychology, 37, 172-177. doi:10.1080/ 00986283.2010 .488555$.

Cluse-Tolar, T., Lambert, E. G., Ventura, L. A., \& Pasupuleti, S. (2005). The views of social work students toward gay and lesbian persons. Journal of Gay \& Lesbian Social Services, 17(3), 5984. doi:10.1300/J041v17n03 04.

Dessel, A. B., Woodford, M. R., \& Warren, N. (2011). Intergroup dialogue courses on sexual orientation: lesbian, gay, and bisexual student experiences and outcomes. Journal of Homosexuality, 58 (8), 1132-1150. doi:10.1080/00918369.2011.598420.

Dillman, D. A., Smyth, J. D., \& Christian, L. M. (2009). Internet, mail, and mixed-mode surveys: the tailored design method. Hoboken: Wiley.

Draughn, T., Elkins, B., \& Roy, R. (2002). Allies in the struggle: eradicating homophobia and heterosexism on campus. Journal of Lesbian Studies, 6(3-4), 9-20.

Finken, L. (2002). The impact of a human sexuality course on anti-gay prejudice. Journal of Psychology and Human Sexuality, 14(1), 37-46. doi:10.1300/J056v14n01_03. 
Fisher, R. D., Derison, D., Polley, C. F., Cadman, J., \& Johnston, D. (1994). Religiousness, religious orientation, and attitudes toward gays and lesbians. Journal of Applied Social Psychology, 24(7), 614-630. doi:10.1111/j.1559-1816.1994.tb00603.x.

Fowler, J. W. (1981). Stages of faith: the psychology of human development and the quest for meaning. San Francisco: Harper \& Row.

Fulton, A. S., Gorsuch, R. L., \& Maynard, E. A. (1999). Religious orientation, antihomosexual sentiment, and fundamentalism among Christians. Journal for the Scientific Study of Religion, 38, 14-22. doi:10.2307/1387580.

Green, J. C. (2004). The American religious landscape and political attitudes: A baseline for 2004. Available from:http://www. uakron.edu/bliss/research.phpi. Accessed on 25 Sept 2011

Greene, B., \& Boyd-Franklin, N. (1996). African American lesbian couples: ethnocultural considerations in psychotherapy. Women and Therapy, 19(3), 49-60. doi:10.1300/J015v19n03_06.

Haider-Markel, D. P., \& Joslyn, M. R. (2005). Attributions and the regulation of marriage: considering the parallels between race and homosexuality. Political Science Politics, 38, 233-239. doi:10.1017/S1049096505056362. DOI:dx.doi.org.

Haider-Markel, D. P., \& Joslyn, M. R. (2008). Beliefs about the origins of homosexuality and support for gay rights: an empirical test of attribution theory. Public Opinion Quarterly, 72, 291-310. doi:10.1093/poq/nfn015.

Hegarty, P. (2002). 'It's not a choice, it's the way we're built': symbolic beliefs about sexual orientation in the US and Britain. Journal of Community \& Applied Social Psychology, 12, 153166. doi:10.1002/casp.669. DOI:dx.doi.org.

Heider, F. (1958). The psychology of interpersonal relations. New York: Wiley.

Herdt, G., \& Kretzner, R. (2006). I do, but I can't: the impact of marriage denial on the mental health and sexual citizenship of lesbians and gay men in the United States. Sexuality Research \& Social Policy, 3, 33-49. doi:10.1525/srsp.2006.3.1.33.

Herek, G. M. (1988). Heterosexuals' attitudes toward lesbians and gay men: correlates and gender differences. Journal of Sex Research, 25, 451-477. doi:10.1080/00224498809551476.

Herek, G. M., \& Garnets, L. D. (2007). Sexual orientation and mental health. Annual Review of Clinical Psychology, 3, 353-375. doi:10.1146/annurev.clinpsy.3.022806.091510.

Highton, B., \& Wolfinger, R. E. (2001). The first 7 years of the political life cycle. American Journal of Political Science, 45, 202-209. doi:10.2307/2669367.

Hillygus, D. S., \& Jackman, S. (2003). Voter decision making in election 2000: campaign effects, partisan activation, and the Clinton legacy. American Journal of Political Science, 47, 583 596. doi:10.1111/1540-5907.00041.

Hillygus, D. S., \& Shields, T. G. (2008). The persuadable voter: wedge issues in presidential campaigns. Princeton: Princeton University Press.

Hinrichs, D., \& Rosenberg, P. (2002). Attitudes toward gay, lesbian, and bisexual persons among heterosexual liberal arts college students. Journal of Homosexuality, 43(1), 61-84. doi:10.1300/ J082v43n01 04.

Hogarth, P. (2010, June 16). As Prop 8 trial concludes, study shows risk of rushing to ballot. The Huffington Post. Available from http://www.huffingtonpost.com/paul-hogarth/as-prop-8-trialconcludes b 614175.html. Accessed on 21 Sept 2010.

Human Rights Campaign (2011a, July 6). Marriage equality \& other relationship recognition laws. Available from http://www.hrc.org/ documents/Relationship_Recognition_Laws_Map.pdf. Accessed on 12 Sept 2011

Human Rights Campaign (2011b, January 13). Statewide marriage prohibitions. Available from http://www.hrc.org/documents/ marriage_prohibitions_2009.pdf. Accessed on 12 Sept 2011.
Jenkins, M., Lambert, E. G., \& Baker, D. N. (2007). The attitudes of Black and White college students toward gays and lesbians. Journal of Black Studies, 39, 589-613. doi:10.1177/ 0021934707299638.

Kaminski, L., \& Walmsley, C. (1995). The advocacy brief: a guide for social workers. The Social Worker, 63, 53-58.

Knox, D., \& Zusman, M.E. (2009, June 26). Sexuality in Black and White: Data from 783 undergraduates. Electronic Journal of Human Sexuality. Available from http://www.ejhs.org/Volume12/ Knox.htm. Accessed on 1 Dec 2010.

Kotler-Berkowitz, L. A. (2005). Ethnicity and political behavior among American Jews: findings from the national Jewish population survey 2000-01. Contemporary Jewry, 25, 132-157. doi:10.1007/BF02965422.

Lannutti, P., \& Lachlan, K. (2008). Assessing attitudes toward samesex marriage. Journal of Homosexuality, 53(4), 113-133. doi:10.1080/00918360802103373.

Lee, B. (2011). Pragmatics of community organization (4th ed.). Toronto: Common Act.

Lewis, G. B. (2003). Black-White differences in attitudes toward homosexuality and gay rights. Public Opinion Quarterly, 67, 5978. doi:10.1086/346009.

Lewis, G. B. (2009). Does believing homosexuality is innate increase support for gay rights? Policy Studies Journal, 37, 669-693. doi:10.1111/j.1541-0072.2009.00330.x

Lewis, G. B., \& Gossett, C. W. (2008). Changing public opinion on same-sex marriage: the case of California. Politics \& Policy, 36, 4-30. doi:10.1111/j.1747-1346.2007.00092.x.

Lucksted, A. (1998). Sexual orientation speakers bureaus. In R. L. Sanlo (Ed.), Working with lesbian, gay, bisexual, and transgender college students: a handbook for faculty and administrators (pp. 351-362). Westport: Greenwood Press.

Mason, C. N. (2009). At the crossroads: African-American attitudes, perceptions, and beliefs toward marriage equality. Washington, DC: National Black Justice Coalition. Available from http://www. nbjc.org/news/marriage_report.pdf. Accessed on 10 Oct 2010.

Milligan, K., Moretti, E., \& Oreopoulos, P. (2003, March). Does education improve citizenship? Evidence from the U.S. and the U.K. UCLA: California Center for Population Research. Retrieved November 1, 2010, from: http://escholarship.org/uc/item/6qw5h964.

Moon, D. (2004). God, sex, and politics: homosexuality and everyday theologies. Chicago: University Chicago Press.

Morales, E. (1992). Latino gays and Latina lesbians. In S. Dworkin \& F. Gutierrez (Eds.), Counseling gay men and lesbians: Journey to the end of the rainbow (pp. 125-139). Alexandria: American Association for Counseling and Development.

Morrison, M. A., \& Morrison, T. G. (2002). Development and validation of a scale measuring modern prejudice toward gay men and lesbian women. Journal of Homosexuality, 43, 15-37. doi:10.1300/J082v43n02_02. DOI:dx.doi.org.

Moskowitz, D., Rieger, G., \& Roloff, M. (2010). Heterosexual attitudes toward same-sex marriage. Journal of Homosexuality, 57(2), 325-336. doi:10.1080/00918360903489176.

Nadal, K. L., Rivera, D. P., \& Corpus, J. H. (2010). Sexual orientation and transgender microaggressions. In D. W. Sue (Ed.), Microaggressions and marginality: manifestation, dynamics, and impact (pp. 217-240). Hoboken: Wiley.

National Gay and Lesbian Task Force. (2010). State laws prohibiting recognition of same-sex relationships. Available from http://www. thetaskforce.org/reports_and_research/marriage_map. Accessed on 28 Sept 2010

Newport, F. (2011, May 20). For first time, majority of Americans favor legal gay marriage: Republicans and older Americans remain opposed. Available from http://www.gallup.com/poll/147662/FirstTime-Majority-Americans-Favor-Legal-Gay-Marriage.aspx. Accessed on 1 Sept 2011. 
Ohlander, J., Batalova, J., \& Treas, J. (2005). Explaining educational influences on attitudes toward homosexual relations. Social Science Research, 34, 781-799. doi:10.1016/j.ssresearch.2004.12.004.

Olson, L. R., Cadge, W., \& Harrison, J. T. (2006). Religion and public opinion about same-sex marriage. Social Science Quarterly, 87, 340-360. doi:10.1111/j.1540-6237.2006.00384.x.

Parks, C. W., Jr. (2010). A window illuminating the reservations of Black men who have sex with men in fully embracing the institution of same-sex marriage. Journal of Gay \& Lesbian Social Services, 22 (1), 132-148. doi:10.1080/10538720903332446.

Pearl, M., \& Galupo, M. P. (2007). Development and validation of the attitudes toward same-sex marriage scale. Journal of Homosexuality, 53(3), 117-134. doi:10.1300/J082v53n03_07.

Peplau, L. A., \& Garnets, L. D. (2000). A new paradigm for understanding women's sexuality and sexual orientation. Journal of Social Issues, 56, 329-350. doi:10.1111/0022-4537.00169. DOI:dx.doi.org.

Powell, G. B. (1986). American voter turnout in comparative perspective. The American Political Science Review, 80, 17-43. doi: $10.2307 / 1957082$.

Pryor, J. H., Hurtado, S., DeAngelo, L., Blake, L. P., \& Tran, S. (2010). The American freshman: national norms, fall 2009. Los Angeles: Higher Education Research Institute.

Raiz, L. (2006). College students' support of rights for members of the gay community. Journal of Poverty, 10(2), 53-76.

Rankin, S. (2003). Campus climate for gay, lesbian, bisexual, and transgender people: a national perspective. New York: The National Gay and Lesbian Task Force Policy Institute.

Rowatt, W. C., LaBouff, J., Johnson, M., Froese, P., \& Tsang, J. (2009). Associations among religiousness, social attitudes, and prejudice in a national random sample of American adults. Psychology of Religion and Spirituality, 1, 14-24. doi:10.1037/ a0014989.

Rye, B. J., \& Meaney, G. (2009). Impact of a homonegativity awareness workshop on attitudes toward homosexuality. Journal of Homosexuality, 56(1), 31-55. doi:10.1080/00918360802551480.

Savin-Williams, R. C., \& Diamond, L. M. (2000). Sexual identity trajectories among sexual-minority youths. Archives of Sexual Behavior, 29, 607-627. doi:10.1023/A:1002058505138.

Sherkat, D. E., de Vries, K. M., \& Creek, S. (2010). Race, religion, and opposition to same-sex marriage. Social Science Quarterly, 91, 80-98. doi:10.1111/j.1540-6237.2010.00682.x.

Span, S. A. (2001). Addressing university students' anti-gay bias: an extension of the contact hypothesis. American Journal of Sexual
Education, 6, 192-205. doi:10.1080/15546128.2011.571957. DOI:dx.doi.org.

Swank, E., \& Raiz, L. (2010). Predicting the support of same-sex relationship rights among social work students. Journal of Gay Lesbian Social Services, 22(1), 149-164. doi:10.1080/ 10538720903332552.

The Defense of Marriage Act 1996 (An Act to Define and Protect the Institution of Marriage of 1996), Public Law 104-199, 104th Congress.

Tygart, C. E. (2000). Genetic causation attribution and public support of gay rights. International Journal of Public Opinion Research, 12, 259-275. doi:10.1093/ijpor/12.3.259.

Tygart, C. E. (2002). Legal rights to homosexuals into the areas of domestic partnerships and marriages: Public support and genetic causation attribution. Educational Research Quarterly, 25(3), 20-28.

Walls, N. E. (2008). Toward a multidimensional understanding of heterosexism: the changing nature of prejudicial attitudes. Journal of Homosexuality, 55, 20-70. doi:10.1080/00918360802129287. DOI:dx.doi.org.

Walls, N. E. (2010). Religion and support for same-sex marriage: implications from the literature. Journal of Gay \& Lesbian Social Services, 22(1), 112-131. doi:10.1080/10538720903332420.

Whitehead, A. L. (2010). Sacred rites and civil rights: religion's effect on attitudes toward same-sex unions and the perceived cause of homosexuality. Social Science Quarterly, 91, 63-79. doi:10.1111/ j.1540-6237.2010.00681.x.

Wiederman, M. W. (2002). Institutional review boards and conducting sexuality research. In M. W. Wiederman \& B. E. Whitley Jr. (Eds.), Handbook for conducting research on human sexuality (pp. 479-504). Mahwah: Erlbaum.

Woodford, M. R. (2010). Same-sex marriage and beyond. Journal of Gay \& Lesbian Social Service, 22(1-2), 1-8. doi:10.1080/ 10538720903332131. DOI:dx.doi.org.

Woodford, M. R., Kolb, C., Radeka. G., \& Javier, G. (2011). Lesbian, gay, bisexual, and transgender ally training programs on campus: Current variations and future directions. Journal of College Student Development (in review).

Woodford, M. R., Luke, K. P., Grogan-Kaylor, A., Fredriksen-Goldsen, K. I., \& Gutierrez, L. (2011). Social work faculty support for samesex marriage: A cross-national study of U.S. and Anglophone Canadian MSW teaching faculty. Social Work Research (in press).

Yetter, G., \& Capaccioli, K. (2010). Differences in responses to Web and paper surveys among school professionals. Behavior Research Methods, 42, 266-272. doi:10.3758/BRM.42.1.266. 